\title{
USABILITY TESTING DENGAN USE QUESTIONNAIRE PADA APLIKASI SIPOLIN PROVINSI JAWA BARAT
}

\author{
Ricky Firmansyah \\ AMIK BSI Bandung \\ Jl. Sekolah Internasional No. 1-6 Antapani Bandung \\ ricky.rym@bsi.ac.id
}

\begin{abstract}
Abstrak
Salah satu sumber pendapatan provinsi berasal dari pajak kendaraan yang disebut PKB Pemprov Jabar sendiri menyebutkan jumlah kendaraan di Jawa Barat pada bulan September 2016 mencapai 15.750.624 unit. Sebanyak 13.447 .117 unit atau 85,38 persen sepeda motor. Pemprov Jabar dan Pemprov Jabar meluncurkan aplikasi Sistem Informasi Pajak Online yang disebut SIPOLIN pada 21 Mei 2017. Aplikasi tersebut diperkenalkan kepada masyarakat terkait kemudahan pembayaran pajak kendaraan secara online. Aplikasi ini bisa diunduh via PlayStore sehingga orang tidak perlu lagi berbaris atau datang ke kantor Samsat. Dalam aplikasi ini, orang akan mengetahui informasi pajak kendaraan mereka. Tingkat kegunaan menjadi patokan, apakah sistem akan berguna, dapat diterima oleh pengguna dan bertahan lama di pasaran. Penelitian ini berfokus pada bagaimana menguji antarmuka pengguna SIPOLIN dengan menggunakan Usability Testing dengan USE Questionnaire pada SIPOLIN versi 1.0. Hasil penelitian ini menunjukkan bahwa semua atribut memiliki nilai rata-rata di atas 3 yang mengindikasikan bahwa SIPOLIN memiliki aspek nilai kegunaan yang sangat baik.
\end{abstract}

Kata Kunci: Antarmuka, Aplikasi, Sipolin, Pajak, Penggunaan

Abstract
One of the provincial revenue source is derived from vehicle tax called PKB. West Java Provincial Government itself states the number of vehicles in West Java at September 2016 reached 15,750,624 units. A total of 13,447,117 units of which or 85.38 percent are motorcycles. West Java Provincial Police and West Java provincial government launched the Online Tax Information System application called SIPOLIN on May 21, 2017. The application introduced to the public related to the ease of paying vehicle taxes online. This application can be downloaded via PlayStore so that people no longer need to line up or come to the Samsat office. In this application, people will know their vehicle tax information. Usability level becomes a benchmark, whether the system will be useful, acceptable to the user and last long in the market. This study focuses on how to test the user interface of SIPOLIN using Usability Testing with USE Questionnaire on SIPOLIN version 1.0. Result of this research is show all attributes have an average value above 3 that indicates SIPOLIN has very good aspect of usability value.

Keywords: application, interface, sipolin, tax, use

\section{Pendahuluan}

Salah satu sumber penerimaan daerah provinsi yang berasal dari pajak adalah pajak kendaraan bermotor (PKB). Pajak kendaraan bermotor adalah pajak atas kepemilikan dan atau penguasaan kendaraan bermotor. Berdasarkan data dari gabungan industri sepeda motor Indonesia (AISI) populasi kendaraan bermotor di Indonesia pada tahun 2010 lalu mencapai 50.824.128 unit dan pada tahun 2014 meningkat menjadi 63.530 .160 unit atau meningkat sebesar 25 persen. Dengan demikian maka adanya peningkatan penggunaan kendaraan bermotor ditengah masyarakat akan memberikan dampak bagi penerimaan daerah yang berasal dari pajak sudah diatur dalam UU RI No 28 Tahun 2009 tentang pajak kendaraan bermotor sebagai komponen pajak propinsi (Anggraini \& Prasetyo, 2014). Pemerintah Provinsi Jawa Barat sendiri menyatakan jumlah kendaraan bermotor di Jawa Barat per September 2016 mencapai 15.750.624 unit. Sebanyak 13.447.117 unit di antaranya atau 85,38 persen adalah kendaraan roda dua atau sepeda motor (Putra, 2016).

Perangkat teknologi membuat masyarakat Jawa Barat semakin mudah dalam melaksanakan proses membayar pajak kendaraan bermotor secara online. 
Polda Jabar bersama Pemprov Jabar meluncurkan aplikasi berlabel Sistem Informasi Pajak Online (Sipolin) pada $21 \mathrm{Mei}$ 2017. Aplikasi Sipolin diperkenalkan kepada masyarakat atau wajib pajak berkaitan kemudahan membayar pajak kendaraan bermotor secara online. Masyarakat tidak perlu lagi antre atau datang ke Samsat. Aplikasi Sipolin ini dapat diunduh melalui Playstore. Dalam aplikasi ini, masyarakat bisa mengetahui informasi pajak kendaraan. Di wilayah hukum Polda Jabar terdapat 14 juta kendaraan yang 70 persennya sudah memenuhi kewajiban membayar pajak (Ramadhan, 2017).

Peningkatan jumlah aplikasi untuk perangkat mobile menantang para pengembang untuk membuat aplikasi dengan kualitas unggul. Ada banyak metode yang dapat digunakan untuk mengukur kualitas sebuah aplikasi, salah satu yang penting adalah usability. Menurut Aelani dan Falahah (2012) dalam (Ola, Suyoto, \& Purnomo, 2016), Tingkat usability menjadi tolak ukur, apakah sistem tersebut akan bermanfaat, dapat diterima oleh pengguna dan bertahan lama di pasaran (Ola, Suyoto, \& Purnomo, 2016). Penelitian ini fokus kepada bagaimana pengujian antarmuka pengguna Aplikasi SIPOLIN menggunakan pengujian Usability? Penelitian ini dibatasi hanya pada pengujian Usability Testing menggunakan USE Questionnaire pada Aplikasi SIPOLIN versi 1.0.

Penelitian serupa dilakukan oleh Rahadi pada Tahun 2014 yang membahas Uji Usability pada Aplikasi Android. Penelitian tersebut dilakukan untuk menganalisis apakah aplikasi Android memiliki akseptabilitas berdasarkan kriteria usability. Penelitian dilakukan dengan menggunakan kuesioner sebagai instrumen penelitian. Berdasarkan pengolahan data diperoleh hasil bahwa dari 5 variabel usability yang digunakan pada kuesioner, hanya 1 variabel yang signifikan digunakan untuk menganalisis usability aplikasi yaitu memorability. Hasil pengujian menunjukkan bahwa nilai penerimaan usability oleh user berada di atas angka 3 (di atas nilai tengah) dalam skala 5 . Faktor yang paling dominan mempengaruhi kenaikan tingkat usability adalah mudah diingat sekaligus berpengaruh positif dalam menaikkan tingkat akseptabilitas aplikasi Android (Rahadi, 2014).
Berikutnya adalah penelitian yang dilakukan oleh Ola, Suyoto dan Purnomo pada tahun 2016. Penelitian ini mengukur usability aplikasi Mangente dengan menggunakan metode kuesioner untuk menentukan tingkat kelayakan dalam penggunaannya. Aspek yang diuji yaitu learnability, flexibility, effectiveness dan attitude. Hasil pengujian terhadap 20 responden didapatkan bahwa nilai usability aplikasi Mangente mencapai 98,54\%. Ini berarti bahwa aplikasi Mangente layak digunakan dan dapat diterima dengan baik di pasaran (Ola, Suyoto, \& Purnomo, 2016).I

\subsection{Usability Testing}

Uji kegunaan aplikasi smartphone terutama dilakukan oleh alat uji kegunaan yang paling umum dalam praktik pengembangan (Ahmad, Boota, \& Maso, 2014). Menurut Nielsen (2012) dalam (Nurhadryani, Sianturi, Hermadi, \& Khotimah, 2013), Usability adalah analisa kualitatif yang menentukan seberapa mudah user menggunakan antarmuka suatu aplikasi. Suatu aplikasi disebut usable jika fungsi-fungsinya dapat dijalankan secara efektif, efisien, dan memuaskan. Efektivitas berhubungan dengan keberhasilan pengguna mencapai tujuan dalam menggunakan suatu perangkat lunak. Efisiensi berkenaan dengan kelancaran pengguna untuk mencapai tujuan tersebut. Kepuasan berkaitan dengan sikap penerimaan pengguna terhadap perangkat lunak. Pengujian usability dilakukan untuk mengevaluasi apakah sebuah aplikasi sudah sesuai dengan kebutuhan pengguna atau belum (Nurhadryani, Sianturi, Hermadi, \& Khotimah, 2013).

\subsection{Aplikasi SIPOLIN}

Sipolin adalah sebuah aplikasi yang digunakan untuk membayar pajak kendaraan bermotor yang dapat dibayar melalui telepon seluler (ponsel). Aplikasi ini resmi diluncurkan Gubernur Jawa Barat Ahmad Heryawan yang didampingi oleh Kapolda Jabar Irjen (Pol) Anton Charliyan, Ketua DPRD Jabar Ineu Purwadewi, Kepala Bapenda Jabar Dadang Suharto, dan Dirut Bank BJB Ahmad Irfan di kawasan Car Free Day Dago Bandung Minggu, 21 Mei 2017. Aplikasi Sipolin tersedia pada layanan Google Playstore pada smartphone berbasis android. Pengguna aplikasi ini diharuskan Login dengan memasukkan datanomor KTP 
dan nomor kendaraan. Nama pemilik kendaraan pada STNK harus sama dengan KTP. Pembayaran untuk sementara hanya bisa melalui Bank BJB. Bukti pembayaran yang ada di aplikasi Sipolin harus diperlihatkan kepada Samsat terdekat saat melakukan pengesahan. Sipolin juga dapat menunjukkan peta dimana Samsat terdekat dengan posisi pengguna. Pengesahan harus dilakukan dengan batas waktu 14 hari sejak pembayaran (Istiqomah \& Putra, 2017).

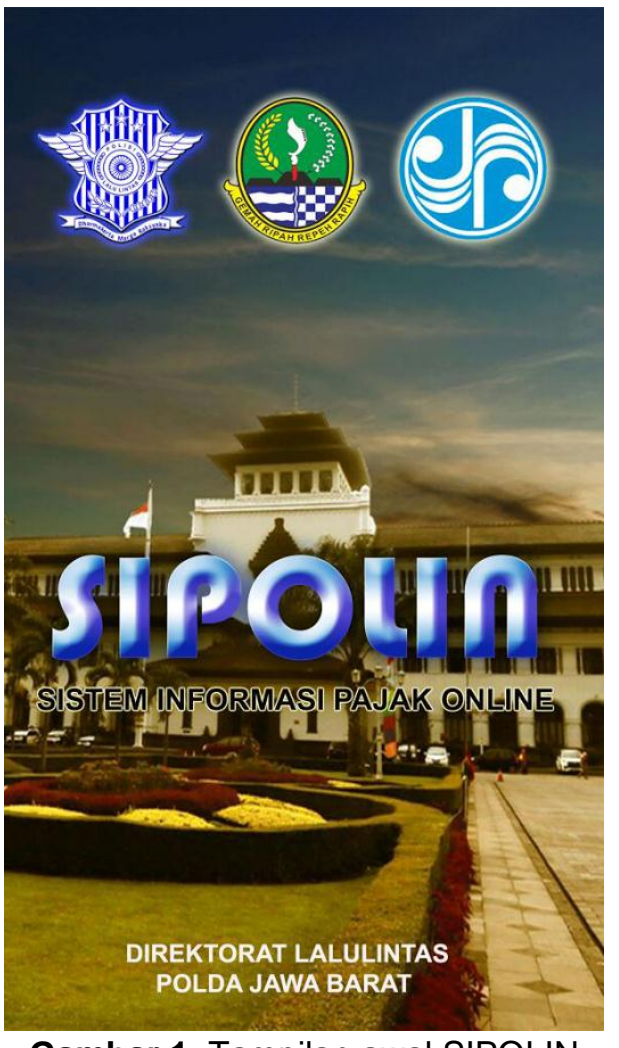

Gambar 1. Tampilan awal SIPOLIN Sumber : PlayStore

\subsection{User Interface}

User interface menyediakan mekanisme bagi user untuk berinteraksi dengan aplikasi. Desain yang baik dari user interface adalah bagian terpenting dari pembuatan aplikasi. Aplikasi dibuat haruslah user-friendly sehingga pengguna akan mudah untuk mempelajari dan menggunakan aplikasi tersebut (Suharli, 2005).

\subsection{USE Questionnaire}

Usefulness, Satisfaction, and Ease of use Questionnaire atau disingkat USE Questionnaire yaitu kuesioner yang biasa digunakan dalam Usability Sistem Komputer. Setiap pertanyaan di dalam kuesioner ini diungkapkan secara positif yang berarti hasil dari hasilnya merespon secara bias. Kuesioner yang menghindari sumber bias ini kerap terjadi pada sumber bias lainnya. Misalnya, beberapa diantaranya adalah tes reliabilitas. Ini berarti bahwa kuesioner yang sama dapat menghasilkan hasil yang berbeda pada waktu yang berbeda (ini dapat diperiksa dengan mengukur reliabilitas uji ulang tes kuesioner). Bahkan kegunaan kuesioner yang lebih sedikit pun dinilai validitasnya. Ini berarti bahwa tidak ada jaminan bahwa kuesioner sebenarnya mengukur kepuasan pengguna (Travis, 2008).

\section{Metode Penelitian \\ 2.1. Populasi dan Sampe Penelitian}

Jumlah responden yang dilibatkan dalam penelitian ini adalah sebanyak 50 responden dari wajib pajak sebagai sampel dari populasi mahasiswa jurusan Sistem Informasi Universitas BSI Bandung.

\subsection{Metode Pengumpulan Data}

Metode pengumpulan data primer dilakukan dengan metode penyebaran angket/kuesioner melalui media survei untuk mendapatkan data. Menurut Sugiyono (1999) dalam Rahadi (2014), menyatakan bahwa Skala Likert digunakan untuk mengukur sikap, pendapat, dan persepsi seseorang atau sekelompok orang tentang fenomena sosial yang merupakan skala kontinum bipolar, pada ujung sebelah kiri (angka rendah) menggambarkan suatu jawaban yang bersifat negatif. Sedang ujung sebelah kanan (angka tinggi), menggambarkan suatu jawaban yang bersifat positif. Skala Likert dirancang untuk meyakinkan responden menjawab dalam berbagai tingkatan pada setiap butir pertanyaan atau pernyataan yang terdapat dalam kuesioner. Data tentang dimensi dari variabel-variabel yang dianalisis dalam penelitian ini yang ditujukan kepada responden menggunakan skala 1 s/d 5 untuk mendapatkan data yang bersifat ordinal dan diberi skor sebagai berikut :

Tabel 1. Tabel Nilai

\begin{tabular}{|r|c|c|c|c|c|}
\hline PK & KMS & KM & CM & M & SM \\
\hline Nilai & 1 & 2 & 3 & 4 & 5 \\
\hline
\end{tabular}

Keterangan :

$\mathrm{PK} \quad=$ Pertanyaan Kuisioner

$\mathrm{CM}=$ Cukup Mudah

KMS = Kurang Mudah Sekali 
$\mathrm{M}=$ Mudah

$\mathrm{KM}=$ Kurang Mudah

$\mathrm{SM}=$ Sangat Mudah

\subsection{Metode Penelitian}

Metode penelitian yang digunakan dalam penelitian ini adalah pengujian usability mengguakan USE Questionnaire.

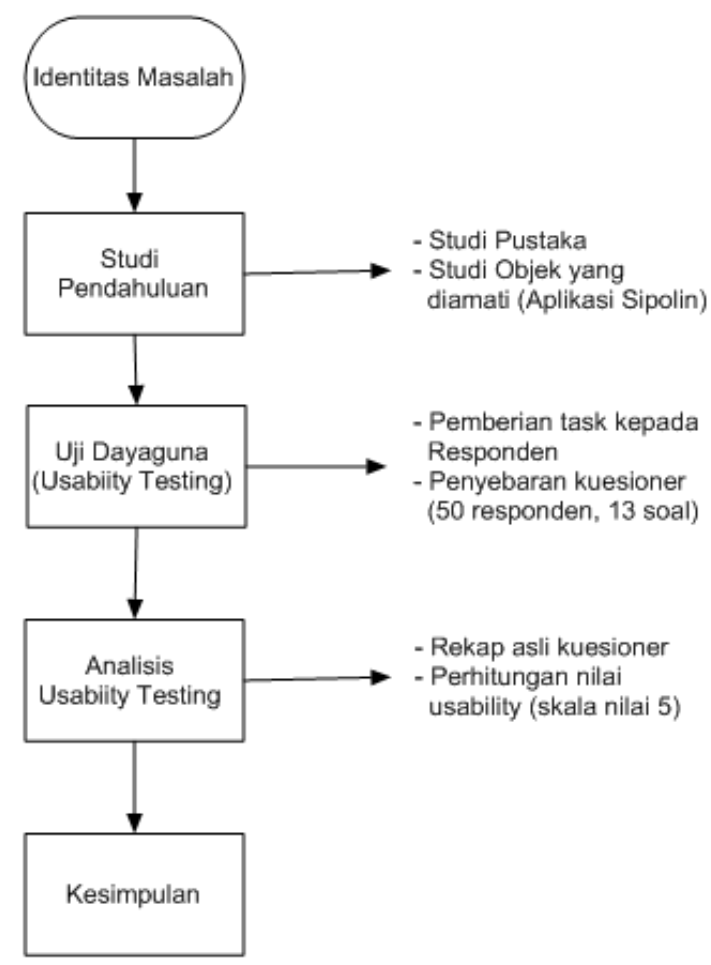

Gambar 2. Alur Metode Penelitian

\section{Hasil Dan Pembahasan \\ 3.1. Usability Testing}

Langkah pertama yang dilakukan dalam usability testing adalah memberikan sejumlah tugas (task) yang sudah dipersiapkan sebelumnya kepada pengguna saat berinteraksi dengan sistem yang diuji. Task-task ini diberikan kepada 50 orang responden yang berasal dari mahasiswa yang sudah mengetahui aplikasi SIPOLIN sehingga mereka tidak lagi mengalami kesulitan pada saat melakukan task-task tersebut. Menurut Sastramihardja dkk (2008) dalam (Rahadi, 2014), task-task ini digunakan sebagai sarana interaksi dalam pengukuran usability.
Tabel 2. Task-task pengujian usability

\begin{tabular}{|l|l|}
\hline No & \multicolumn{1}{|c|}{ Task / Tugas } \\
\hline 1 & $\begin{array}{l}\text { Buka aplikasi SIPOLIN dan perhatikan } \\
\text { menu yang ada. }\end{array}$ \\
\hline 2 & $\begin{array}{l}\text { Buka menu Informasi Kendaraan dan } \\
\text { Pajak }\end{array}$ \\
\hline 3 & $\begin{array}{l}\text { Buka menu Registrasi Online. } \\
\text { Inputkan data kendaraan masing- } \\
\text { masing dan lihat hasilnya pada } \\
\text { informasi kendaraan dan pajak atau } \\
\text { pada menu Registrasi Online. }\end{array}$ \\
\hline 5 & \begin{tabular}{l} 
Mencari informasi lokasi Samsat. \\
\hline
\end{tabular} \\
\hline
\end{tabular}

Berikut ini adalah penjelasan dari masing-masing task tersebut:

Task 1. Pengguna membuka aplikasi SIPOLIN dan memperhatikan tampilan menu.

Task 2. Pengguna mengakses dan mencoba menu Informasi Kendaraan dan Pajak dengan menginputkan data kendaraan miliknya.

Task 3. Pengguna mengakses menu Registrasi Online dan mencoba mendaftar.

Task 4. Pengguna melihat tampilan huruf dan gambar informasi pajak kendaraan miliknya.

Task 5. Pengguna mencoba akses Informasi Lokasi Samsat dengan keadaan GPS aktif dan tidak aktif.

Kuesioner diberikan kepada responden yang telah mengerjakan task-task di atas agar mendapatkan pengalaman pengguna (user experience) terhadap tampilan aplikasi yang diuji yaitu apa yang dilihat dan dirasakan pengguna saat melakukan task yang diberikan. Kuesioner berisi 13 pertanyaan yang mewakili kelima aspek usability. Menurut pendapat Wingnjosoebroto et. Al. 2009 dalam Rahadi (2014) setiap pertanyaan dalam kuesioner tersebut bertujuan untuk menunjukkan tingkat usability menurut penerimaan user yang akan dinilai dalam skala 5 .

Menurut Mazumder \& Das (2014) dalam Firmansyah (2016), Organisasi Standar Internasional (International Standard Organization, ISO) mendefinisikan bahwa 
daya guna (Usability) adalah sejauhmana suatu produk dapat digunakan oleh pengguna untuk mencapai tujuan mereka dengan efektif dan efisien. Daya guna memiliki lima atribut kualitas yaitu (Firmansyah, 2016):

1. Learnability, yaitu menunjukkan betapa mudahnya pengguna dapat mempelajari fungsi sistem utama dan mencapai keterampilan untuk melakukan pekerjaan.

2. Efisiensi, yaitu setelah mempelajari sistem, seberapa cepat pengguna dapat melakukan tugas mereka menggunakan sistem.

3. Memorability, sangat penting bagi pengguna yang tidak teratur untuk dapat menggunakan sistem tanpa harus belajar lagi. Fitur ini membantu pengguna untuk mengingat sistem bekerja setelah periode penggunaan tertentu.

4. Error, yaitu jumlah kesalahan pengguna dan bagaimana dengan mudah mereka dapat memulihkannya.

5. Satisfaction, yaitu menunjukkan bahwa menyenangkan atau tidaknya pengguna dalam menggunakan sistem.

Hasil plot kelima aspek usability di atas terhadap 13 pertanyaan kuesioner dapat dilihat pada table 3 berikut.

Tabel 3. Plot Aspek Usability

\begin{tabular}{|c|c|c|c|c|c|c|}
\hline \multirow{2}{*}{$\begin{array}{l}\mathbf{N} \\
\mathbf{0}\end{array}$} & \multirow[b]{2}{*}{ Pertanyaan } & \multicolumn{5}{|c|}{ Aspek Usability } \\
\hline & & $\begin{array}{l}\mathbf{L} \\
\mathbf{R}\end{array}$ & $\begin{array}{l}\mathbf{E} \\
\mathbf{F}\end{array}$ & $\begin{array}{c}\mathbf{M} \\
\mathbf{R}\end{array}$ & $\begin{array}{l}\mathbf{E} \\
\mathbf{R}\end{array}$ & $\begin{array}{l}\mathbf{S} \\
\mathbf{F}\end{array}$ \\
\hline \multicolumn{7}{|c|}{ ASPEK SISTEM (SYSTEM) } \\
\hline 1 & $\begin{array}{l}\text { Apakah } \\
\text { tampilan } \\
\text { antarmuka } \\
\text { aplikasi } \\
\text { SIPOLIN } \\
\text { mudah di } \\
\text { kenali? }\end{array}$ & & & & & \\
\hline 2 & $\begin{array}{l}\text { Apakah } \\
\text { SIPOLIN } \\
\text { mudah } \\
\text { dioperasikan }\end{array}$ & & & & & \\
\hline 3 & $\begin{array}{l}\text { Apakah } \\
\text { tampilan } \\
\text { warna pada } \\
\text { SIPOLIN } \\
\text { nyaman } \\
\text { dilihat dan } \\
\text { tidak } \\
\text { membosanka } \\
\text { n? }\end{array}$ & & & & & \\
\hline
\end{tabular}

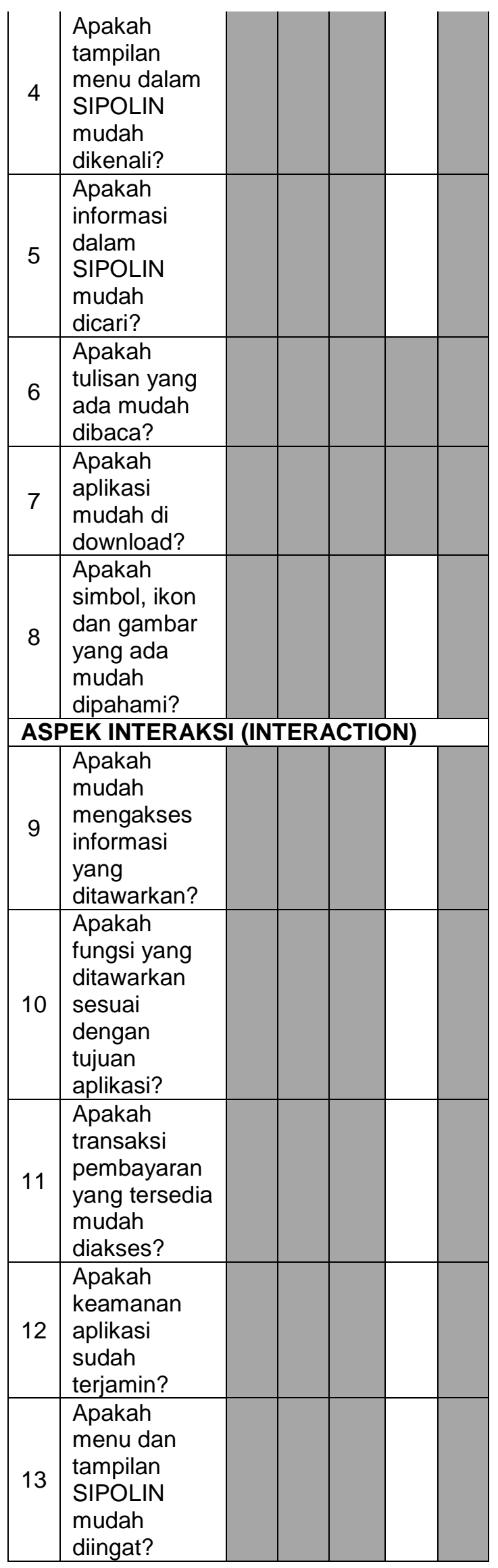


Keterangan :

$\begin{array}{ll}\text { LR } & =\text { Learnability } \\ \text { EF } & =\text { Efficiency } \\ \text { MR } & =\text { Memorability } \\ \text { ER } & =\text { Error } \\ \text { SF } & =\text { Satisfaction }\end{array}$

\subsection{Analisa Usability Testing}

Selanjutnya adalah melakukan rekap terhadap hasil kuesioner yang telah disebarkan kepada 50 responden. Hasil perhitungan rata-rata terhadap hasil usability testing di atas, maka diperoleh rekap nilai usability yang dapat dilihat pada table $4 \mathrm{di}$ bawah ini.

Tabel 4. Rekap Nilai Usability

\begin{tabular}{|c|c|c|}
\hline No & Pertanyaan & Nilai \\
\hline \multicolumn{3}{|c|}{ ASPEK SISTEM (SYSTEM) } \\
\hline 1 & $\begin{array}{l}\text { Apakah tampilan antarmuka } \\
\text { aplikasi SIPOLIN mudah di } \\
\text { kenali? }\end{array}$ & 3.64 \\
\hline 2 & $\begin{array}{l}\text { Apakah SIPOLIN mudah } \\
\text { dioperasikan }\end{array}$ & 3.50 \\
\hline 3 & $\begin{array}{l}\text { Apakah tampilan warna pada } \\
\text { SIPOLIN nyaman dilihat dan } \\
\text { tidak membosankan? }\end{array}$ & 3.00 \\
\hline \multicolumn{3}{|c|}{ ASPEK PENGGUNA (USER) } \\
\hline 4 & $\begin{array}{l}\text { Apakah tampilan menu dalam } \\
\text { SIPOLIN mudah dikenali? }\end{array}$ & 3.48 \\
\hline 5 & $\begin{array}{l}\text { Apakah informasi dalam } \\
\text { SIPOLIN mudah dicari? }\end{array}$ & 3.54 \\
\hline 6 & $\begin{array}{l}\text { Apakah tulisan yang ada } \\
\text { mudah dibaca? }\end{array}$ & 4.04 \\
\hline 7 & $\begin{array}{l}\text { Apakah aplikasi mudah di } \\
\text { download? }\end{array}$ & 3.70 \\
\hline 8 & $\begin{array}{l}\text { Apakah simbol, ikon dan } \\
\text { gambar yang ada mudah } \\
\text { dipahami? }\end{array}$ & 3.70 \\
\hline \multicolumn{3}{|c|}{ ASPEK INTERAKSI (INTERACTION) } \\
\hline 9 & $\begin{array}{l}\text { Apakah mudah mengakses } \\
\text { informasi yang ditawarkan? }\end{array}$ & 3.54 \\
\hline 10 & $\begin{array}{l}\text { Apakah fungsi yang } \\
\text { ditawarkan sesuai dengan } \\
\text { tujuan aplikasi? }\end{array}$ & 3.64 \\
\hline 11 & $\begin{array}{l}\text { Apakah transaksi pembayaran } \\
\text { yang tersedia mudah diakses? }\end{array}$ & 3.50 \\
\hline 12 & $\begin{array}{l}\text { Apakah keamanan aplikasi } \\
\text { sudah terjamin? }\end{array}$ & 3.18 \\
\hline 13 & $\begin{array}{l}\text { Apakah menu dan tampilan } \\
\text { SIPOLIN mudah diingat? }\end{array}$ & 3.58 \\
\hline
\end{tabular}

Berdasarkan table 4 di atas, dapat dilihat bahwa untuk atribut "simbol, ikon dan gambar yang ada mudah dipahami” memiliki nilai peneriamaan usability user sebesar 3,70 yang arinya sudah berada di atas 3 atau nilai tengah dalam skala 5 . Hal ini berarti aplikasi SIPOLIN telah dibuat mudah untuk dikenali oleh user dari segi tampilan antarmuka. Bila disesuaikan dengan plot aspek usability pada table 3 , aplikasi SIPOLIN telah dibuat dengan memiliki nilai usability, yaitu: Learnability, Efficiensy, Memorability, Errors dan Satisfavtion yang sangat baik. Hal ini dapat ditunjukkan dengan nilai hasil usability pada kelima atribut, sebagai berikut:

1. Nilai atribut "simbol, ikon dan gambar yang ada mudah dipahami" sebesar 3,70 menunjukan bahwa aplikasi telah memiliki nilai Learnability.

2. Nilai atribut "informasi dalam SIPOLIN mudah dicari" sebesar 3,54 menunjukan bahwa aplikasi telah memiliki nilai Efficiency.

3. Nilai atribut "menu dan tampilan SIPOLIN mudah diingat" sebesar 3,58 menunjukan bahwa aplikasi telah memiliki nilai Memorability

4. Nilai atribut "mudah mengakses informasi yang ditawarkan" sebesar 3,54; atribut "tulisan yang ada mudah dibaca" sebesar 4,04; dan atribut "ditawarkan sesuai dengan tujuan aplikasi" sebesar 3,64 membuat aplikasi SIPOLIN telah meminimalisasi aspek Errod.

5. Keseluruhan atribut yang memiliki nilai rata-rata di atas 3 menunjukkan bahwa aplikasi SIPOLIN mempunyai aspek Satisfaction yang sangat baik.

\section{Penutup}

\subsection{Kesimpulan}

Berdasarkan hasil rekap nilai usability yang memiliki nilai penerimaan usability user di atas 3, maka dapat disimpulkan bahwa Aplikasi SIPOLIN telah memiliki aspek nilai usability yang sangat baik. Nilai atribut terkecil ada pada aspek warna tampilan dan keamanan pada aplikasi. USE Questionnaire dapat digunakan untuk mengukur daya guna suatu antarmuka perangkat lunak.

\subsection{Saran}

Beberapa saran yang dapat penulis berikan adalah sebagai berikut:

1. Aplikasi ini bertujuan untuk pelayanan terhadap publik (wajib pajak) sehingga nilai kepuasan terhadap antarmuka 
aplikasi harus diimbangi dengan nilai kepuasan layanan.

2. Pengembangan aplikasi versi berikutnya perlu memperhatikan dari sisi warna pada tampilan antarmuka, keamanan dan server yang sering tidak merespon.

3. Peneliti berikutnya dapat menambahkan atau menggunakan metode lain untuk meningkatkan akurasi.

\section{Referensi}

Ahmad, N., Boota, M. W., \& Maso, A. H. (2014). Smart Phone Application Evaluation with Usability Testing Approach. Journal of Software Engineering and Applications, 10461054.

Anggraini, P., \& Prasetyo, F. (2014). EFILING SEBAGAI PERAN INDONESIA DALAM MEMBERIKAN APRESIASI DAN KONTRIBUSI MENDUKUNG KOMUNITAS ASEAN DALAM KEMUDAHAN PELAYANAN PAJAK. JURNAL KHATULISTIWA INFORMATIKA, VOL. 2 NO. 2, -207.

Firmansyah, R. (2016). EVALUASI HEURISTIK PADA DESAIN INTERFACE APLIKASI MY INDIHOME. Seminar Nasional IImu Pengetahuan dan Teknologi Komputer 4 (1) (pp. 66-73). Bekasi: STMIK Nusa Mandiri.

Istiqomah, Z., \& Putra, Y. M. (2017, Mei 21). Jabar Luncurkan Aplikasi Bayar Pajak Kendaraan Lewat Ponsel. Retrieved Oktober 11, 2017, from Republika Online: http://nasional.republika.co.id/berita/ nasional/pemprovjabar/17/05/21/oqaorv284-jabarluncurkan-aplikasi-bayar-pajakkendaraan-lewat-ponsel

Nurhadryani, Y., Sianturi, S. K., Hermadi, I., \& Khotimah, H. (2013). Pengujian
Usability untuk Meningkatkan Antarmuka Aplikasi Mobile. Jurnal IImu Komputer dan Agri-Informatika Volume 2 Nomor 2, 83-93.

Ola, Y. Y., Suyoto, S., \& Purnomo, S. (2016). PENGUJIAN USABILITY ANTARMUKA APLIKASI MANGENTE. Seminar Nasional Teknologi Informasi dan Komunikasi 2016 (SENTIKA 2016) (pp. 334342). Yogyakarta: SENTIKA 2016.

Putra, Y. M. (2016, Oktober 17). Jumlah Kendaraan Bermotor Jabar Capai 15,7 Juta Unit. Retrieved Oktober 3, 2017, from Republika Online: http://www.republika.co.id/berita/nas ional/daerah/16/10/17/of75b1284jumlah-kendaraan-bermotor-jabarcapai-157-juta-unit

Rahadi, D. R. (2014). Pengukuran Usability Sistem Menggunakan Use Questionnaire Pada Aplikasi Android. Jurnal Sistem Informasi (JSI), VOL. 6, NO. 1, 661-671.

Ramadhan, D. I. (2017, Mei 21). Gubernur dan Kapolda Jabar Luncurkan Aplikasi Sipolin. Retrieved Oktober 3, 2017, from DetikNews: https://news.detik.com/berita-jawabarat/d-3507185/gubernur-dankapolda-jabar-luncurkan-aplikasisipolin

Suharli, S. (2005). Membangun Aplikasi Berbasis Windows Dengan Vb .net. Jakarta: PT. Elex Media Komputindo.

Travis, D. (2008, Maret 3). Measuring satisfaction: Beyond the usability questionnaire. Retrieved Oktober 11, 2017, from User Experience Consulting \& UX Training: http://www.userfocus.co.uk/articles/s atisfaction.html 